\title{
Pengaruh Model AIR Dan TTW Terhadap Kemampuan Representasi Siswa SMP Di Kota Singkawang
}

\author{
Sari $^{1}$, Nurul Husna ${ }^{2}$ \\ ${ }^{1,2}$ Pendidikan Matematika, STKIP Singkawang \\ Penulis Korespondensi: nuna husna@ymail.com
}

\begin{abstract}
: he learning model is a framework that provides a systematic description for carrying out learning in order to help students learn in certain goals to be achieved. Two of the learning models that can be used are the Auditory Intellectually Repetition (AIR) learning model and the Think Talk Write (TTW) learning model. This study aims to describe the comparison of the effect between the AIR and TTW models on the representation ability of junior high school (SMP) students in Singkawang City. The type of research used in this research is quantitative with a quasi-experimental design using a non-equivalent posttest-only control group design. This research was conducted at SMP Negeri 13 Singkawang, namely the students of class VIII C as experimental class 1 (using the AIR Model) totaling 21 students and VIII D as experimental class 2 (using the TTW Model) totaling 25 students, selected from 4 class by purposive sampling. The instruments used are in the form of mathematical representation ability questions and observation sheets for student learning activities. Data analysis using Effect-Size test and two-samples independent comparation hypothesis testing. The results of this study are (1) the AIR learning model gives a better effect than the TTW model on mathematical representation ability with a large effect of 0.98 (large category); (2) Learning activities while using the AIR learning model are better than the TTW learning model.
\end{abstract}

\section{Keywords: Auditory Intellectually Repetition (AIR), Think Talk Write (TTW), student representation} ability.

\begin{abstract}
Abstrak: Model pembelajaran merupakan kerangka kerja yang dapat memberikan gambaran sistematis untuk melaksanakan pembelajaran sehingga dapat membantu siswa belajar sesuai dengan tujuan tertentu yang ingin dicapai. Model pembelajaran tersebut diantaranya yaitu model pembelajaran Auditory Intellectually Repetition (AIR) dan Think Talk Write (TTW). Penelitian ini bertujuan untuk mendeskripsikan perbandingan pengaruh antara model AIR dan TTW terhadap kemampuan representasi siswa Sekolah Menengah Pertama (SMP) di Kota Singkawang. Jenis penelitian yang digunakan dalam yaitu penelitian kuantitatif dengan desain quasi-eksperimental menggunakan rancangan non-equivalent posttestonly control group design. Penelitian ini dilakukan di SMP Negeri 13 Singkawang, yaitu pada siswa kelas VIII C sebagai kelas ekperimen 1 (menggunakan Model AIR) yang berjumlah 21 siswa dan VIII D yang sebagai kelas ekperimen 2 (menggunakan Model TTW) yang berjumlah 25 siswa, yang dipilih dari 4 kelas dengan purposive sampling. Instrumen yang digunakan yaitu soal kemampuan representasi matematis dan lembar onservasi aktivitas belajar siswa. Analisis data menggunakan pengujian Effect-Size dan hipotesis komparasi dua sampel independent. Hasil dari penelitian ini adalah (1) model pembelajaran pembelajaran AIR memberikan pengaruh yang lebih baik dari pada model TTW terhadap kemampuan representasi matematis dengan besar pengaruh 0,98 (kategori besar); (2) Aktivitas belajar selama menggunakan model pembelajaran AIR lebih baik dari pada model pembelajaran TTW.
\end{abstract}

Kata kunci: Auditory Intellectually Repetition (AIR), Think Talk Write (TTW), kemampuan representasi siswa.

\section{PENDAHULUAN}

Kemampuan representasi matematis merupakan kemampuan matematis yang perlu dikembangkan dan dimiliki oleh siswa ketika belajar matematika di sekolah, karena dapat membangun pemahaman konseptual dan kelancaran procedural, serta mengkomunikasikan ide 
atau gagasan matematis dari yang bersifat abstrak menjadi lebih konkret sehingga lebih mudah untuk dipahami oleh siswa. Kemampuan representasi matematis merupakan juga menjadi kemampuan yang sangat penting bagi siswa karena termasuk dalam tujuan yang hendak dicapai dalam pembelajaran matematika di sekolah (Sabirin, 2014). beberapa pendapat seperti Janvier (1987), Hartoyo (2010), Hutagaol (2013), Sulastri et al. (2017), Ningrum et al. (2018), Husna \& Nurhayati (2018), Nurdianti et al. (2019), juga menyatakan bahwa representasi dapat mendorong siswa dalam memahami konsep matematika, untuk berkomunikasi menggunakan matematika, untuk berargumentasi, mengenali keterkaitan antar konsep matematika, dan menerapkan metematika realistis menggunakan permodelan mateamtis.

Representasi matematis adalah ungkapan beragam secara tertulis yang digunakan untuk menyatakan suatu gagasan atau ide-ide yang terdapat dalam matematika yang secara umum dapat dinyatakan dengan sajian secara verbal, visual, dan simbolik. Sajian verbal adalah menerjemahkan masalah matematika menjadi suatu kalimat. Sajian visual adalah menerjemahkan masalah matematika ke dalam gambar, grafik atau tabel. Sedangkan sajian simbol adalah menerjemahkan masalah matematika ke dalam simbol matematiks atau rumus aritmatika matematika. Oleh karena itu, kemampuan representasi dapat digunakan siswa untuk membangun pemahaman konseptual, kelancaran procedural dan komunikasi matematis siswa yang merupakan tujuan pertama pembelajaran matematika siswa di tingkat SMP/MTs dalam kurikulum 2013 dan Learning Principle NCTM.

Berdasarkan tujuan pembelajaran matematika dan Learning Principle NCTM, disebutkan bahwa siswa seharusnya memiliki kemahiran dalam mengembangkan konsep dan prosedur ke berbagai representasi untuk memecahkan permasalahan matematika. Namun berdasarkan beberapa hasil penelitian dinyatakan bahwa kemampuan siswa dalam merepresentasikan masalah matematika masih rendah. Hal tersebut berdasarkan hasil penelitian Kholiqowati, H; Sugiarto, Hidayah (2016), Asyrofi \& Junaedi (2016) dan Astuti (2017) yang menyatakan bahwa kemampuan representasi visual dan verbal sangat rendah. hal tersebut juga didukung dengan hasil penelitian Nadia \& Isnarto (2017) yang menyatakan kurang mampunya siswa dengan self efficacy kategori cukup dan rendah dalam menggunakan semua sajian representasi. Selain itu, Triono (2017) dalam penelitiannya mengungkapkan bahwa rata- rata kemampuan representasi matematis siswa pada materi SPLDV dan Teorema Phytagoras yaitu 59,84. Rata - rata nilai untuk setiap indikator yaitu representasi simbol sebesar 65,66, dan representasi verbal dan gambar di bawah rata-rata nilai representasi simbol. Jika dikaitkan dengan nilai Kriteria Ketuntasan Minimal (KKM) siswa masih belum mencapai nilai KKM. Berdasarkan hasil penelitian tersebut dapat dinyatakan bahwa kemampuan representasi siswa dalam belajar matematika masih rendah, dengan representasi yang dominan adalah representasi simbolik. 
Representasi penting dimiliki oleh siswa karena dapat mendorong siswa dalam merepresentasikan ide-ide siswa dengan cara yang masuk akal. Kemapuaqn Representasi berperan penting dalam membantu siswa memahami dan memecahkan masalah, memberikan cara yang bermakna untuk mengingat suatu prosedur dan mendeskripsikan prosedur yang lainya, serta dapat digunakan untuk menyelidiki ide-ide matematika. Dengan mengkaitkan pengalaman siswa di kehidupan dengan ide-ide matematika dapat membuat hasil pembelajaran lebih bermakna (Ulfah \& Abidin, 2016). Dengan demikian, siswa kemudian dapat membangun, memperbaiki, dan menggunakan representasi siswa sendiri sebagai alat untuk mendukung pembelajaran dan mengerjakan matematika. Terkait dengan bagaimana siswa mengkomunikasikan ide dengan berbagai macam representasi (multirepresentasi), guru sebagai fasilitator berperan penting membantu siswa belajar untuk menggunakan representasi dengan fleksibel dan tepat. Di antara cara guru membantu mengembangkan representasi siswa adalah dengan mendukung pemikiran dan komunikasi siswa dengan mengembangkan fasilitas pembelajaran dengan berbagai model pembelajaran. Dua di antara model pembelajaran yang dapat digunakan yaitu model pembelajaran Auditory Intellectually Repetition (AIR) dan model pembelajaran Think Talk Write (TTW).

Model pembelajaran AIR (Auditory, Intellectually dan Repetition) merupakan suatu pembelajaran yang efektif untuk mendukung kemampuan siswa dalam belajar dengan memperhatikan tiga hal yaitu: (a) Auditory berarti indra telinga yang digunakan dalam belajar dengan cara menyimak, berbicara, presentasi, argumentasi, mengemukakan pendapat, dan menanggapi; (b) Intellectually berarti kemampuan berpikir yang perlu dilatih melalui latihan bernalar, mencipta, memecahkan masalah, mengkonstruksi, dan menerapkan; dan (c) Repetition berarti pengulangan diperlukan dalam pembelajaran agar pemahaman lebih mendalam dan lebih luas, peserta didik perlu dilatih melalui pengerjaan soal, pemberian tugas atau kuis (Maulana, 2012). Model pembelajaran AIR diharapkan dapat memberikan pengaruh positif terhadap kemampuan multi representasi siswa karena dalam proses pembelajaran dengan model AIR siswa dituntut untuk dapat menggunakan alat indera dengan cara menyimak, berbicara dan presentasi. Berdasarkan penjelasan tersebut, model pembelajaran AIR dapat digunakan untuk meningkatkan kemampuan representasi matematis siswa karena siswa diharapkan dapat mengemukakan ide tidak hanya melalui lisan, tetapi juga dalam bentuk gambar (visual), kata-kata (verbal), dan ekspresi matematis.

Beberapa hasil penelitian menyatakan bahwa model pembelajaran AIR dapat memberikan hasil positif terhadap hasil pembelajaran. Diantaranya penelitian Alan \& Afriansyah (2017) dan Fitri \& Utomo (2016) yang menyatakan bahwa model pembelajaran AIR efektif untuk menigkatkan hasil belajar siswa. Selain itu, Latifah (2014) dan Purwati et al. (2018) juga menunjukkan bahwa model pembelajaran Auditory Intellectually Repetition (AIR) dengan 
pendekatan RME efektif terhadap kemampuan komunikasi matematis peserta didik. Sejalan dengan hasil penelitian tersebut, model pembelajaran Auditory Intellectually Repetition (AIR) juga dapat memberikan pengaruh positif terhadap kemampuan multi representasi siswa karena indikator pada kemampuan komunikasi matematis mirip dengan indikator pada kemampuan representasi matematis.

Sedangkan model pembelajaran TTW dianggap dapat memperbaiki serta merangsang peserta didik untuk lebih aktif dalam mengikuti kegiatan pembelajaran karena dibangun melalui proses berpikir (Think), berbicara (Talk), dan menulis (Write). Siswa diberikan waktu untuk mengeksplor ide-ide atau gagasan yang mereka miliki secara mandiri dengan mengerjakan soal yang ditentukan, selanjutnya membahas atau membicarakan hasil pemikirannya pada saat diskusi kelompok, dan siswa dituntut untuk menuliskan hasil diskusi kelompok secara individu. Dengan demikian, dapat melatih siswa untuk lebih aktif baik secara individu maupun berkelompok dan siswa akan terbiasa untuk bekerjasama dan berinteraksi dengan teman kelompoknya untuk bertukar pendapat atau ide dalam mengerjakan tugas. Dengan demikian siswa lebih mudah memahami materi yang diajarkan oleh guru. Berdasarkan hasil penelitian, model pembelajaran TTW juga dapat digunakan untuk meningkatkan hasil belajar siswa. Di antaranya yaitu penelitian Astin et al. (2015), Angkotasan \& Jalal (2017), Surya (2017) dan Nuraeni \& Luritawaty (2016) yang menyatakan bahwa model TTW dapat digunakan untuk mengembangkan kemampuan representasi siswa.

Satu diantara faktor yang dapat mendukung keberhasilan proses pembelajaran yaitu aktivitas belajar siswa. Dalam proses belajar mengajar, guru sangat berperan untuk mengatur aktivitas belajar siswa karena aktivitas merupakan prinsip atau asas yang sangat penting dalam interaksi belajar mengajar (Masjudin \& Hayatunnupus, 2014). "Aktivitas belajar merupakan serangkaian kegiatan pembelajaran yang dilakukan siswa selama proses pembelajaran" (Masita, 2012). Selanjutnya Lestari \& Yudhanegara (2015) menyatakan bahwa keaktivan belajar merupakan keterlibatan siswa dalam proses pembelajaran dengan tujuan agar memiliki keberhasilan dalam belajar. Aktivitas belajar siswa dapat diklasifikasikan menjadi: (a) Visual activities, yaitu aktivitas membaca, menyimak gambar demonstrasi, dan dan melakukan percobaan; b) Oral activities, yaitu aktivitas seperti merumuskan suatu permasalahan, bertanya, memberi saran dan pendapat, serta diskusi interupsi; c) Listening aktivities, yaitu aktivitas seperti mendengarkan pemaparan materi dari guru atau dari sumber belajar lain; d) Writing activities, yaitu aktivitas seperti menuliskan hasil diskusi, jawaban dari soal yang diberikan, dan aktivitas menemukan jawaban dari soal matematika yang menggunakan tulisan; e) Drawing activities, yaitu aktivitas seperti menggambar, membuat grafik, peta, diagram untuk menemukan jawaban dari permasalahan yang diberikan; f) Motor activities yaitu aktivitas seperti melakukan 
percobaan, bermain, berkebun, beternak; g) Mental activities, contohnya: menanggapi suatu permaslaahan, mengingat, memecahkan soal, menganalisis; h) Emotional activities, seperti: minat, merasa bosan, gembira, bersemangat, bergairah, berani, tenang, gugup (Sardiman, 2014). Adapun indikator aktivitas yang akan diteliti yaitu visual aktivities, writing activities, listening aktivities, oral activities dan drawing activities.

Berdasarkan pembahasan tersebut, dapat disimpulkan bahwa model pembelajaran AIR dan TTW dapat digunakan untuk mengembangkan kemampuan representasi siswa sehingga berdampak pada hasil belajar siswa. Oleh karena itu dalam penelitian ini, akan dilakukan penelitian tentang perbandingan pengaruh model AIR dan TTW terhadap kemampuan representasi siswa Sekolah Menengah Pertama (SMP) di Kota Singkawang. Adapun tujuan dari penelitian ini adalah untuk mengetahui besarnya pengaruh model AIR dan TTW terhadap kemampuan representasi siswa serta mengetahui perbedaan kemampuan representasi antara siswa yang mendapat pembelajaran dengan model AIR dengan model TTW pada siswa SMP di kota Singkawang, serta mengetahui aktivitas belajar siswa selama menggunakan model pembelajaran AIR dan TTW.

\section{METODE}

Jenis penelitian yang digunakan adalah penelitian kuantitatif, sedangkan Metode yang digunakan adalah Metode eksperimen. Metode penelitian eksperimen merupakan metode penelitian yang digunakan untuk mencari pengaruh perlakuan tertentu terhadap yang lain dalam kondisi yang dikendalikan (Sugiyono, 2017). Adapun desain yang digunakan dalam penelitian ini desain quasi-eksperimental dengan rancangan yang digunakan adalah nonequivalent posttest-only control group design. Penelitian ini dilakukan di SMP Negeri 13 Singkawang, yaitu pada siswa kelas VIII. Adapun yang menjadi sampel penelitian yaitu siswa kelas VIII C sebagai kelas ekperimen 1 yang berjumlah 21 siswa dan VIII D yang sebagai kelas ekperimen 2 yang berjumlah 25 siswa yang dipilih dari 4 kelas dengan purposive sampling, yaitu pemilihan sample yang tidak dilakukan secara acak, dengan tujuan tertentu.Kelas ekperimen 1 adalah kelas yang diberi pembelajaran dengan model AIR, dan kelas ekperimen 2 adalah kelas yang yang diberi pembelajaran dengan model TTW. Pada desain nonequivalent posttest-only control group, harus ada kelas yang dijadikan sebagai kelas control, maka kelas ekperimen 2, yaitu pembelajaran dengan model TTW dijadikan sebagai kelas control. Desain nonequivalent posttest-only control group dapat dilihat pada gambar berikut. 
X

(pembelajaran dengan model AIR)
$\mathrm{O}$

(postes di kelas X)
$\mathrm{C}$
(pembelajaran dengan model TTW)
$\mathrm{O}$

(pembelajaran dengan model TTW)

\section{Gambar 1.}

Instrument yang digunakan dalam penelitian ini yaitu, tes kemampuan representasi yang disusun berdasarkan indikator kemampuang representasi, dan lembar pengamatan aktivitas yang disusun berdasarkan indikator aktivitas siswa yaitu visual aktivities, writing activities listening aktivities, oral activities dan drawing activities.

Teknik analisis data yang digunakan untuk menguji perbedaan dalam penelitian ini adalah pengujian komparasi 2 sampel independen. Karena data yang diperoleh berdistribusi normal, maka uji yang digunakan yaitu uji-t dua sampel independen dengan pengujian satu pihak (uji pihak kanan). untuk menghitung besarnya pengaruh model Pembelajaran AIR dan TTW terhadap hasil pembelajaran menggunakan effect sizeuntuk 2 kelompok Cohen dengan rumus

$d=\frac{\overline{X_{1}}-\overline{X_{2}}}{s_{g a b}}$ dengan $S_{g a b}=\sqrt{\frac{\left(n_{1}-1\right) s_{1}^{2}+\left(n_{2}-1\right) s_{2}^{2}}{\left(n_{1}+n_{2}-2\right)}}$

Untuk mengetahui aktivitas siswa dalam belajar matematika menggunakan model AIR dan TTW yaitu dengan menghitung persentase setiap indikator aktivitas pembelajaran yang dilakukan $\left(P_{i}\right)$.

$\left(P_{i}\right)=\frac{f_{i}}{n} \times 100 \%$

Keterangan :

$P_{i} \quad=$ presentase aktivitas indikator ke- $i$

$f_{i}=$ frekwensi siswa yang melakukan aktivitas indikator ke- $i$

$\mathrm{n}$ = jumlah seluruh siswa yang mengikuti pembelajaran. 
Selanjutnya persentase aktivitas siswa akan ditafsirkan berdasarkan kriteria berikut.

Tabel 1. Kriteria Penafsiran Aktivitas Siswa

\begin{tabular}{cc}
\hline Kriteria & Penafsiran \\
\hline $\mathrm{Pi}=0 \%$ & Tak seorang pun siswa aktif \\
$0 \%<\mathrm{Pi}<25 \%$ & Sebagian kecil siswa aktif \\
$25 \% \leq \mathrm{Pi}<50 \%$ & Hampir setengah siswa aktif \\
$\mathrm{Pi}=50 \%$ & Setengahnya siswa aktif \\
$50 \%<\mathrm{Pi}<75 \%$ & Sebagian besar siswa aktif \\
$75 \% \leq \mathrm{Pi}<100 \%$ & Hampir seluruhnya siswa aktif \\
$\mathrm{Pi}=100 \%$ & Seluruh Siswa Aktif \\
\hline & (Lestari \& Yudhanegara, 2015)
\end{tabular}

\section{HASIL DAN PEMBAHASAN}

Berdasarkan penilaian terhadap hasil postest diperoleh perbedaan rata-rata nilai siswa berdasarkan indikator representasi matematis antara pembelajaran model AIR dengan TTW yang dapat dilihat pada Gambar 2 berikut.

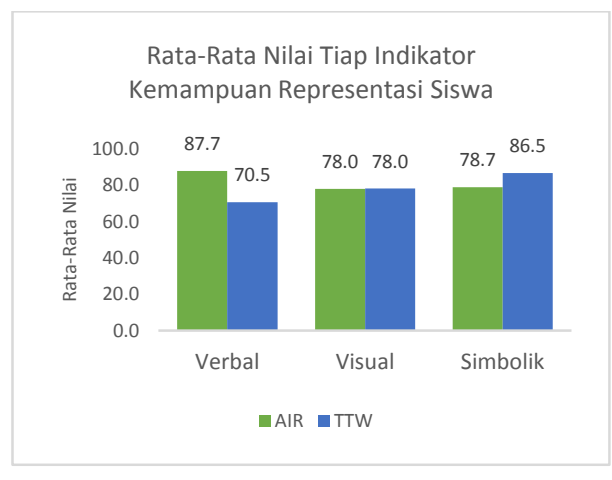

Gambar 2. Rata-rata nilai Kemampuan representasi siswa antara model AIR dengan TTW untuk setiap indikator

Berdasarkan Gambar 2 diperoleh informasi bahwa kemampuan representasi verbal siswa dengan pembelajaran model AIR lebih tinggi dibandingkan dengan pembelajaran model TTW. Sedangkan kemampuan representasi simbolik siswa dengan model TTW lebih tinggi dibandingkan dengan model AIR. Untuk kemampuan representasi visual siswa dengan model AIR dan TTW mempuanyai rata-rata nilai yang sama. Berdasarkan hasil analisi data postes siswa, diperoleh hasil penelitian yang disajikan dalam Table 2 berikut. Secara keseluruhan, rata-rata nilai siswa pada kategori tuntas. Untuk data lengkapnya, dapat di lihat pada Tabel 2 berikut. 
Tabel 2. Hasil Analisis Data Postest

\begin{tabular}{lll}
\hline & Model AIR & Model TTW \\
\hline $\mathbf{N}$ & 21 & 25 \\
\hline Rata-rata nilai postest & 82 & 78,4 \\
\hline SD & 9,67 & 16,43 \\
\hline Effect- Size & $\mathbf{0 , 9 8}$ & \\
& $($ Berpengaruh besar) \\
\hline t-hitung & $\mathbf{3 , 3 2 8}$ & \\
\hline t-tabel & $\mathbf{2 , 0 1 5}$ & \\
\hline $\begin{array}{l}\text { keputusan } \\
\text { Kesimpulan: }\end{array}$ & Ho ditolak dan Ha diterima \\
$\begin{array}{l}\text { Rata-rata nilai kemampuan representasi siswa yang } \\
\text { mendapat pembelajaran AIR lebih tinggi dari rata- } \\
\text { rata nilai kemampuan } \\
\text { mendapat pembelajaran dengan TTW }\end{array}$ \\
\hline \begin{tabular}{l} 
siswa yang \\
\hline
\end{tabular}
\end{tabular}

Berdasarkan hasil analisis dalam Tabel 2, diperoleh informasi bahwa rata-rata nilai siswa dengan model pembelajaran AIR lebih tinggi dari rata-rata nilai siswa dengan model pembelajaran TTW. Dari table juga diketahui nilai t hitung adalah 3,328 dan nilai t table dengan nilai alfa $(\alpha) 5 \%$ atau 0,05 adalah 2,015. Berdasarkan ketentuan keputusan uji hipotesis komparasi dua sampel pihak kanan, jika nilai t hitung lebih kecil dari t table maka hipotesis nol (Ho) di terima, dan hipotesis alternative (Ha) di tolak. Diketahui bahwa nilai t hitung lebih besar dari $\mathrm{t}$ table, yang berarti bahwa Ho di tolak dan Ha diterima. Dari keputusan tersebut, dapat disimpulkan bahwa bahwa rata-rata nilai kemampuan representasi siswa yang mendapat pembelajaran model AIR lebih tinggi dari rata-rata nilai kemampuan representasi siswa yang mendapat pembelajaran model TTW. Model AIR berpengaruh besar terhadap kemampuan representasi siswa dengan besar nilai effect sizenya adalah 0,98 (berpengaruh besar).

Jika ditinjau dari analisi data pada hasil observasi aktivitas siswa dengan menggunakan model AIR dengan TTW, diperoleh informasi bahwa aktivitas belajar siswa dengan menggunakan model AIR lebih baik daripada aktivitas belajar dengan model TTW. Data lengkapnya dapat dilihar pada Gambar 3 berikut. 


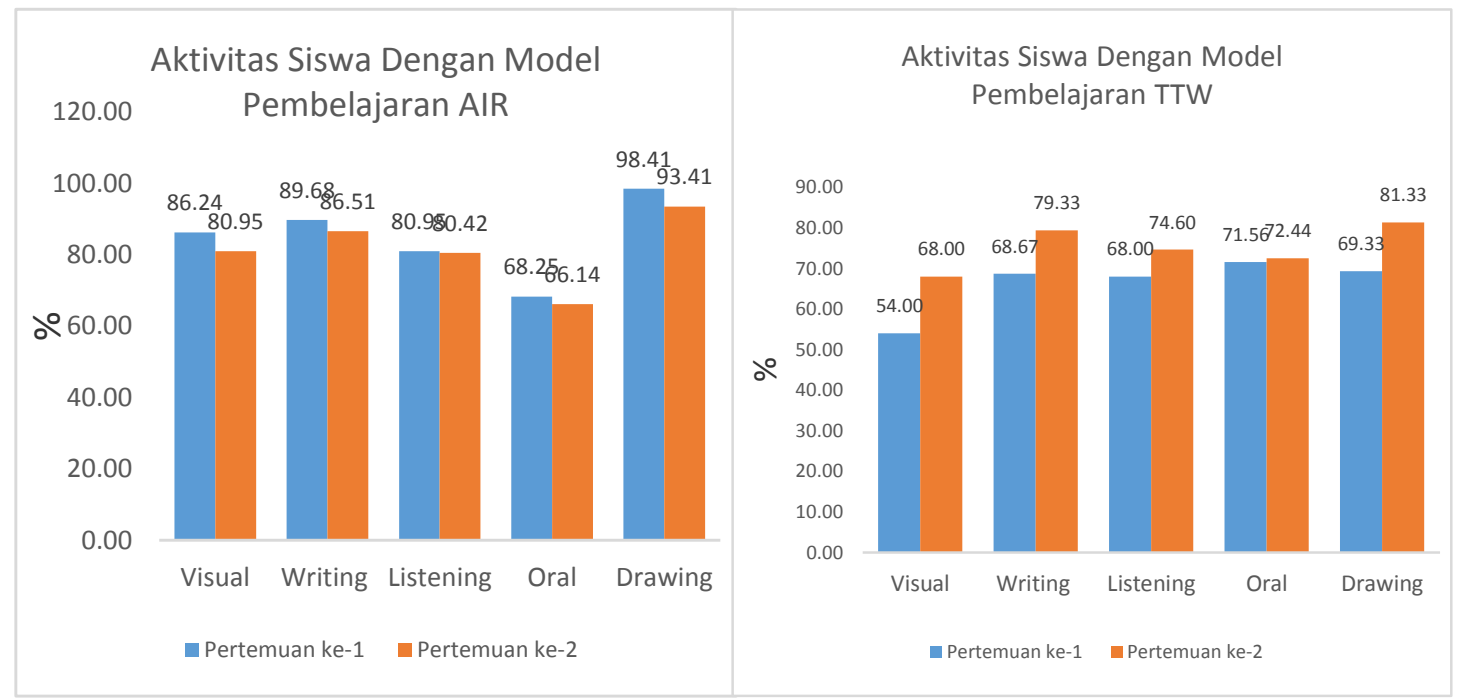

Gambar 3. Aktivitas belajar siswa dengan pembelajaran AIR dan TTW

Berdasarkan data pada Gambar 3, dapat dideskripsikan secara umum aktivitas di AIR lebih baik dari pada TTW. Persentase aktivitas yang paling tinggi dilakukan siswa selama diterapkan model pembelajaran AIR dan TTW adalah drawing. Sedangkan untuk aktivitas yang paling endah dilakukan siswa yaitu oral activity pada AIR, dan visual activity pada TTW. Untuk aktivitas verbal siswa lebih baik pada model pembelajaran AIR sedangkan aktivitas Simbolik lebih baik pada model pembelajaran TTW. Berdasarkan hasil analisis terhadap aktivitas tersebut, kemampuan representasi siswa setelah menggunakan model pembelajaran AIR lebih baik dari kemampuan representasi siswa setelah menggunakan model pembelajaran TTW karena aktivitas siswa pada model AIR lebih baik dari model TTW. Pada proses pembelajaran matematika, sebenarnya aktivitas dalam membuat simbol matematika secara tidak langsung dilakukan, karena matematika merupakan aktivitas tentang mengoperasikan simbol matematika. Tetapi untuk dapat memahami simbol tersebut, seseorang memerlukan sajian dengan menggunakan gambar dan pernyataan yang dapat memperjelas simbol matematika tersebut. Karena model pembelajaran AIR lebih memfasilitasi untuk belajar dengan menggunakan ketiga representasi tersebut, maka kemampuan terpresentasi siswa lebih baik dari kemampuan representasi pada model TTW.

\section{SIMPULAN}

Terdapat perbedaan pengaruh penerapan model AIR dan TTW terhadap kemampuan representasi siswa Sekolah Menengah Pertama (SMP) Negeri 13 Singkawang, dengan jawaban rumusan sub masalah sebagai berikut:

1. Model AIR meberikan berpengaruh yang besar $(0,98)$ terhadap kemampuan representasi siswa SMP N 13 Singkawang. 
2. Rata-rata nilai kemampuan representasi siswa yang mendapat pembelajaran AIR lebih tinggi dari rata-rata nilai kemampuan representasi siswa yang mendapat pembelajaran dengan TTW.

3. Aktivitas selama menggunakan model pembelajaran AIR lebih baik dari pada aktivitas selama menggunakan model pembelajaran TTW.

\section{UCAPAN TERIMA KASIH}

Ucapan terima kasih disampaikan kepada Direktorat Jenderal Pendidikan Tinggi, Riset, dan Teknologi, Kementrian Pendidikan Kebudayaan, Riset, dan Teknologi untuk mendukung pendaan melalui Program Talenta Inovasi Indonesia Ta 2021 Gelombang 1.

\section{DAFTAR PUSTAKA}

Alan, U. F., \& Afriansyah, E. A. (2017). Kemampuan Pemahaman Matematis Siswa melalui Model Pembelajaran Auditory Intellectualy Repetition dan Problem Based Learning. Jurnal Pendidikan Matematika, 11(1), 67-78.

Angkotasan, N., \& Jalal, A. (2017). Perbandingan Model Pembelajaran Problem Solving dengan Model Pembelajaran Kooperatif Tipe Think Talk Write (TTW) pada Materi Program Linier terhadap Aspek Kemampuan Representasi Matematis Mahasiswa. SAINTIFIK@, 1(2).

Astin, A. E., Coesamin, M., \& Djalil, A. (2015). Efektivitas Model Pembelajaran Kooperatif Tipe TTW Ditinjau dari Kemampuan Representasi Matematis. JURNAL PENDIDIKAN MATEMATIKA UNIVERSITAS LAMPUNG, 3(2).

Astuti, E. P. (2017). Representasi Matematis Mahasiswa Calon Guru dalam Menyelesaikan Masalah Matematika. Beta: Jurnal Tadris Matematika, 10(1), 70-82.

Asyrofi, M. A. M., \& Junaedi, I. (2016). Kemampuan Representasi Matematis Ditinjau dari Multiple Intellingence pada Pembelajaran Hybrid Learning berbasis Konstruktivisme. Unnes Journal of Mathematics Education Research, 5(1), 32-39.

Fitri, S., \& Utomo, R. B. (2016). Pengaruh Model Pembelajaran Auditory, Intellectually, and Repetition terhadap Kemampuan Pemahaman Konsep di SMP Pustek Serpong. JURNAL EDuMath, 2(2).

Hartoyo, A. (2010). Mode Representasi Ide dalam Belajar Matematika. Jurnal Pendidikan Matematika Dan IPA, 1(1).

Husna, N., \& Nurhayati, N. (2018). Pengembangan Pembelajaran Scientific Berbasis Multirepresentasi Untuk Menunjang Pembelajaran Matematika dalam Kurikulum 2013. JPMI (Jurnal Pendidikan Matematika Indonesia), 3(2), 74-80.

Hutagaol, K. (2013). Pembelajaran Kontekstual untuk Meningkatkan Kemampuan Representasi 
Matematis Siswa Sekolah Menengah Pertama. Infinity Journal, 2(1), 85-99.

Janvier, C. E. (1987). Problems of Representation in the Teaching and Learning of Mathematics.

This Book Stems from a Symposium Organized by CIRADE (Centre Interdisciplinaire de Recherche Sur l" Apprentissage et Le Développement En Education) of Université Du Quelbec Abec Abec Abec Abec Abec Abec Abec Abec Abec Abec Abec Abec Abec Abec Abec à Montr.

Kholiqowati, H; Sugiarto, Hidayah, I. (2016). Analisis Kemampuan Representasi Matematis Ditinjau dari Karakteristik Cara Berfikir Peserta Didik dalam Pembelajaran dengan Pendekatan Saintifik. UJME, 5(3).

Latifah, N. U. (2014). Keefektifan Model Pembelajaran AIR dengan Pendekatan RME terhadap Kemampuan Komunikasi Matematik Materi Geometri Kelas VII. Universitas Negeri Semarang.

Lestari, K. E., \& Yudhanegara, M. R. (2015). Penelitian Pendidikan Matematika. Bandung: PT Refika Aditama, 2(3).

Masita, M. (2012). Peningkatan Aktivitas Siswa pada Pembelajaran Matematika melalui Pendekatan Kontekstual (Contextual Teaching and Learning). Jurnal Pendidikan Matematika, l(1).

Masjudin, M., \& Hayatunnupus, H. (2014). Teori Belajar Skinner Berbasis Talking Stick untuk Meningkatkan Aktivitas dan Prestasi Belajar Siswa. Media Pendidikan Matematika, 2(1), $21-28$.

Maulana, A. (2012). Model Pembelajaran AIR Untuk Meningkatkan Kemampuan Komunikasi Matematika Siswa. Bandung: FMIPA UPI.

Nadia, L. N., \& Isnarto, I. (2017). Analisis Kemampuan Representasi Matematis Ditinjau dari Self Efficacy Peserta Didik melalui Inductive Discovery Learning. Unnes Journal of Mathematics Education Research, 6(2), 242-250.

Ningrum, A. S., Susanto, H., \& Mindyarto, B. N. (2018). Pengembangan Media Charta Free Body Diagram (FBD) yang Moveable untuk Meningkatkan Kemampuan Multirepresentasi Siswa pada Materi Kesetimbangan dan Dinamika Rotasi. UPEJ Unnes Physics Education Journal, $7(3), 43-50$.

Nuraeni, R., \& Luritawaty, I. P. (2016). Mengembangkan Kemampuan Komunikasi Matematik Siswa melalui Strategi Think Talk Write. Mosharafa: Jurnal Pendidikan Matematika, 5(2), 101-112.

Nurdianti, D., Rohaeti, E. E., \& Senjayawati, E. (2019). Analisis Kemampuan Koneksi Matematik Siswa Kelas XII Madrasah Aliyah Kota Cimahi Pada Materi SPLDV. Journal on Education, 1(2), 126-131. 
Purwati, D., Sessu, A., \& Jusra, H. (2018). Pengaruh Model Pembelajaran Auditory Intellectually Repetition (Air) terhadap Kemampuan Komunikasi Matematis Siswa Smp. Prosiding SENAMKU, 1, 240-249.

Sabirin, M. (2014). Representasi dalam Pembelajaran Matematika. Jurnal Pendidikan Matematika, 1(2), 33-44.

Sardiman, A. M. (2014). Interaksi \& Motivasi Belajar Mengajar (cetakan ke 22). Jakarta: PT. Raja Grafindo Persada.

Sulastri, S., Marwan, M., \& Duskri, M. (2017). Kemampuan Representasi Matematis Siswa SMP melalui Pendekatan Pendidikan Matematika Realistik. Beta: Jurnal Tadris Matematika, 10(1), 51-69.

Surya, E. (2017). Perbandingan Kemampuan Komunikasi Matematis Siswa Yang Belajar Dengan Model Pembelajaran Kooperatif Tipe Think Talk Write dan Tipe Think Pair Share di SMP Negeri 3 Percut Sei Tuan. INSPIRATIF: JURNAL PENDIDIKAN MATEMATIKA, 3(3).

Triono, A. (2017). Analisis Kemampuan Representasi Matematis Siswa Kelas VIII SMP Negeri 3 Tangerang Selatan.

Ulfah, M., \& Abidin, Z. (2016). Penerapan Model Pembelajaran Eliciting Activities (MEAs) untuk Meningkatkan Aktivitas dan Hasil Belajr Siswa Kelas X SMAN 1 Sekotong pada Materi Pokok Perbandingan Trigonometri. Media Pendidikan Matematika, 4(1), 20-27. 